\title{
IMPROVING SPEAKING SKILL AND DEVELOPING CHARACTER OF THE STUDENTS THROUGH COLLABORATION OF THINK-PAIR-SHARE AND THE CONCEPT OF TRI KAYA PARISUDHA
}

\author{
I Komang Budiarta, Ni Wayan Krismayani \\ English Education Study Program, Faculty of Teacher Training and Education \\ Mahasaraswati Denpasar University \\ mrbudi@live.com
}

\begin{abstract}
ABSTRAK
Keterampilan berbicara merupakan salah satu keterampilan yang harus selalu dilatih agar mereka dapat berkomunikasi dengan baik.Di samping itu, karakter juga merupakan salah satu hal yang sangat penting karena orang yang sukses bukan hanya karena hard skill tetapi juga soft skill.Penelitian ini ditujukan untuk mengatasi permasalahan yang dihadapi oleh mahasiswa semester tiga Program Studi Pendidikan Bahasa Inggris yaitu keterampilan berbicara dan karakter.Penelitian dilaksanakan dalam beberapa siklus penelitian tindakan kelas dengan menerapkan model pembelajaran kolaborasi think-pair-share dengan konsep tri kaya parisudha.Setelah beberapa siklus, hasil penelitian menunjukkan terjadinya peningkatan dari pra siklus sampai siklus IV.Hal ini menunjukkan bahwa model pembelajaran yang diterapkan telah berhasil meningkatkan keterampilan berbicara dan mengembangkan karakter disiplin, jujur, kooperatif, kreatif dan saling menghormati.
\end{abstract}

Kata kunci: keterampilan berbicara, karakter, think-pair-share dan tri kaya parisudha. 


\section{PENDAHULUAN}

Hakikat pentingnya peningkatan keterampilan berbicara tidak sejalan dengan proses pembelajaran yang ada di kelas khususnya di Program Studi Pendidikan Bahasa Inggris Fakultas Keguruan dan Ilmu Pendidikan Universitas Mahasaraswati Denpasar (PSP Bahasa Inggris FKIP Unmas Denpasar). Para mahasiswa di dalam mata kuliah Speaking (berbicara) belum mampu mengekspresikan ide atau gagasan dalam Bahasa Inggris lisan. Sebagai contoh, mereka terkadang berhenti ditengah pembicaraan tanpa tahu harus berkata apa dan mahasiswa juga kurang berani memulai berbicara dalam bahasa Inggris.

Keterampilan berbicara merupakan salah satu keterampilan yang sangat kurang dikuasai oleh mahasiswa semester III PSP Bahasa Inggris FKIP Unmas Denpasar tahun akademik 2013/2014. Hal ini dapat dilihat dari hasil observasi awal yang peneliti lakukan dengan mewawancarai beberapa dosen yang mengajar di semester III dan berdasarkan hasil dari mata kuliah Speaking II yang telah mereka ambil di semester II. Hasil ini menunjukkan bahwa proses pembelajaran keterampilan berbicara belum berlangsung dengan maksimal. Di samping itu, banyak dosen yang mengeluh tentang bagaimana buruknya perilaku mahasiswa semester II yang sekarang menjadi semester III.

Ketidakmampuan mereka dalam mengungkapkan ide dengan bahasa Inggris secara lisan sejalan dengan perilaku mereka yang tidak mencerminkan karakter Bangsa Indonesia yang selalu dibangga-banggakan misalnya berbicara sopan, ramah, jujur, dan lain-lain. Hal ini membuat masyarakat semakin yakin bahwa degradasi moral yang terjadi adalah bukti kegagalan pendidikan

Degradasi moral ini juga sangat terasa di dalam kelas ketika para dosen memasuki kelaskelas di PSP Bahasa Inggris FKIP Unmas Denpasar. Para mahasiswa tidak disiplin, ketika mengerjakan ujian mereka mencontek, berkata yang tidak sopan, tidak kreatif dan lain-lain. Oleh karena itu, di beberapa kelas, dosen sering mengalami 'intimidasi' akibat dari tingkah laku para mahasiswa yang tidak berkarakter sehingga para dosen tidak dapat melakukan proses pembelajaran dengan maksimal untuk mencapai tujuan yang telah ditetapkan.

Hal ini harus segera ditangani karena pendidikan karakter merupakan salah satu hal penting untuk membangun karakter peserta didik dan orang-orang yang memiliki karakter yang baik adalah para calon orang sukses. Seperti yang kita ketahui bahwa kesuksesan seseorang tidak hanya diukur dari pengetahuan akademisnya atau hard skill saja tetapi juga pada soft skill salah satunya karakter. Hal ini mengisyaratkan bahwa proses pembelajaran harus dilakukan secara seimbang

Namun fakta yang terlihat di kelas-kelas PSP Bahasa Inggris FKIP Unmas Denpasar, proses pembelajaran Bahasa Inggris tidak berlangsung secara seimbang. Masih banyak dosen yang hanya menekankan pemberian aspek kognitif dan psikomotorik atau hard skill kepada para peserta didik dan bahkan mengabaikan pentingnya aspek afektif atau soft skill khususnya karakter. Hal ini terjadi karena beberapa faktor dan salah satunya adalah masih kurang kreatifnya para pendidik dalam mencari dan memodifikasi teknik pembelajaran yang mampu mengakomodasi pembelajaran kedua skill tersebut.

Dalam penelitian ini, peneliti menawarkan sebuah model pembelajaran yang dimodifikasi dengan mengkolaborasikan salah satu model pembelajaran kooperatif tipe Think-Pair-Share dengan salah satu konsep kehidupan dalam Agama Hindu yaitu Tri Kaya Parisudha. Dalam model pembelajaran ini, peneliti tidak ingin mencampuri kebebasan beragama peserta didik atau subjek penelitian dan model pembelajaran ini tidak ada kaitannya dengan proses menghindukan peserta didik non-Hindu.

Konsep yang ditawarkan oleh Tri Kaya Parisudha yaitu manacika: berpikir yang bersih dan suci, wacika: berkata yang benar,dan kayika: berbuat yang benar. Konsep Tri Kaya Parisudha yang dikolaborasikan dengan Think-Pair-Share, secara sederhana dapat digambarkan sebagai berikut: peserta didik akan dilatih untuk selalu berpikir yang baik secara individu (Think-

Manacika), kemudian mereka akan berdiskusi 
dengan temannya atau pasangannya (Pair-Wacika) dan diakhiri dengan membagikan gagasan hasil diskusi mereka dengan teman-teman yang lain di dalam kelas dan juga akan diharapkan berlanjut di luar kelas (Share-Kayika).

Model ini diharapkan mampu mengakomodasi proses pembelajaran yang tidak hanya menekankan pada peningkatan keterampilan berbicara peserta didik tetapi juga pengembangan karakter-karakter yang mengarah pada pengembangan karakter yang baik. Selain itu, juga diharapkan dapat memberikan atmosfer yang berbeda dibandingkan dengan model pembe-lajaran konvensional yang sering diterapkan oleh para dosen yang cenderung monoton dan kaku.

Dalam penelitian ini permasalahan dibatasi dalam ruang lingkup peningkatan keterampilan berbicara dalam mata kuliah Speaking III dan pengembangan karakter seperti disiplin, jujur, bertanggung jawab, kreatif dan saling menghormati.

\section{METODE PENELITIAN}

Penelitian ini menggunakan desain Penelitian Tindakan Kelas (PTK). Penelitian ini akan dilaksanakan dalam beberapa siklus dengan dua sesi untuk setiap siklus danpada setiap sesi terdapat empat kegiatan yang saling berhubungan: Perencanaan (Planning), Aksi (Action), Observasi (Observatio), dan Refleksi (Reflection).

Tempat pelaksanaan penelitian adalah PSP Bahasa Inggris FKIP Unmas Denpasar. Penelitian dilaksanakan di Kampus Soka yang berada di Jalan Soka Nomor 47. Subjek penelitian ini adalah semester IIIA yang berjumlah 30 orang (11 orang laki-laki dan 19 orang perempuan).

Untuk mengumpulkan data-data yang diperlukan dalam penelitian ini, peneliti menggunakan tiga macam instrumen penelitian yaitu tes yang terdiri dari dua jenis tes yang dinilai dengan menggunakan rubrik penilaian analitik dengan kriteria-kriteria seperti kelancaran (fluency/40 poin), pemahaman (comprehension/35 poin), tata bahasa (grammar/15 poin), dan kealamiannya (naturality/10 poin): pre-tes dan posttes, character checklisti dan kuesioner untuk mendapatkan data pendukung. Metode pengumpulan data dilakukan dengan active participatory observation.

Pre-tes diberikan sebelum proses penelitian untuk melihat kemampuan awal dalam berbicara. Setelah proses pembelajaran dilakukan, di akhir setiap siklus, diberikan post-tes yang digunakan untuk mengetahui peningkatan kemampuan subjek dalam berbicara. Sedangkan character checklist diberikan di setiap akhir siklus dan digunakan untuk mendapatkan data tentang perkembangan perilaku subjek penelitian serta kuesioner yang diberikan di akhir siklusuntuk mengetahui respon mereka terhadap model pembelajaran yang diberikan.Data yang didapat kemudian dianalisa dengan menggunakan rumus nilai rata-rata dan prosentase.

Untuk melihat keberhasilan penelitian tindakan kelas ini, ada dua indikator yang digunakan yaitu peningkatan keterampilan berbicara dan perkembangan karakter subjek penelitian.Untuk keterampilan berbicara, subjek penelitian harus mencapai nilai di atas 75 yang merupakan standar kelulusan minimal untuk mata kuliah speaking III.

Sedangkan untuk perkem-bangan karakter subjek penelitian, penelitian akan dihentikan jika perkembangan karakter mereka sudah memenuhi prosentase minimal yaitu $50 \%$ membudaya konsisten.

\section{HASIL DAN PEMBAHASAN}

\section{Hasil}

Penelitian tindakan kelas merupakan cyclical proses yang dilakukan secara kontinu. Penelitian ini ditujukan untuk meningkatkan keterampilan berbicara dan mengembangkan karakter peserta didik dengan menggunakan model pembelajaran kolaborasi think-pair-share dengan konsep tri kaya parisudha. Data-data yang terkumpul dapat dideskripsikan sebagai berikut:

\section{Observasi Awal}

Penelitian ini didahului dengan melakukan observasi awal terhadap subjek yang akan diamati. Untuk mendapatkan gambaran yang lebih terukur tentang keterampilan berbicara dan perkembangan 
karakter subjek penelitian, pre-tes dan character checklist diberikan kepada mereka.

Berdasarkan hasil perhitungan skor pre-tes didapatkan nilai rata-rata 52,33 yang dikategorikan 'kurang'. Sedangkan untuk mengumpulkan data tentang perkembangan awal karakter peserta didik, character checklist diberikan kepada subjek penelitian.Mereka diminta untuk mengisi ceklist sesuai dengan keadaan mereka tanpa ada rekayasa. Karakter-karakter tersebut antara lain: disiplin, jujur, kooperatif, kreatif, dan saling menghormati.

Berdasarkan hasil perhitungan character checklist didapat prosentase-prosentase karakter yang sudah membudaya konsisten sebagai berikut: karakter disiplin sebesar 5,56\%; karakter jujur sebesar 12.50\%; karakter kooperatif sebesar 1,39\%; karakter kreatif sebesar 0,00\%; dan 13,89\% karakter saling menghormati. Prosentase ini menunjukkan bahwa kelima karakter tersebut belum membudaya konsisten dalam perilaku subjek penelitian khususnya dalam proses pembelajaran.

\section{Siklus I}

Siklus I terdiri dari empat langkah yang secara kontinu harus dilakukan yaitu: perencanaan, aksi, observasi, dan refleksi. Materi yang diajarkan di siklus I adalah Asking and Offering Help.Berdasarkan hasil dari pre-tes, pasangan subjek penelitian juga disiapkan. Pasangan ini diusahakan berbeda dalam konteks tingkat keterampilan berbicara dan jenis kelamin serta latar belakang sosial yang lain. Pada siklus I, subjek penelitian diberikan post-tes dan character checklistdengan hasil sebagai berikut:

Post-tes I diberikan kepada semua subjek penelitian yang hadir yaitu 30 orang. Penampilan mereka dinilai dengan menggunakan rubrik penilaian.Setelah mendapatkan nilai setiap subjek, kemudian nilai rata-rata keterampilan berbicara di siklus I dihitung. Hasi perhitungan ini menghasilkan nilai rata-rata sebesar 59,63 yang dikategorikan 'cukup'. Hal ini menunjukkan adanya peningkatan dari nilai rata-rata pre-tes yang hanya 52,33 ('kurang').

Character checklist II yang diberikan kepada subjek penelitian juga menunjukkan hasil yang memuaskan karena penerapan model pembelajaran kolaborasi think-pair-share dengan konsep tri kaya parisudha sudah mampu mengubah prosentase karakter yang membudaya konsisten. Hasil ceklist karakter menunjukkan: 36,11\% karakter disiplin; 25,00\% karakter jujur; 29,17\% karakter kooperatif $11,11 \%$ karakter kreatif dan 29,17\% karakter saling menghormati.

\section{Siklus II}

Siklus II tidak jauh berbeda dengan siklus I. Namun berdasarkan hasil dari siklus I, perbaikanperbaikan yang diperlukan untuk meningkatkan keterampilan berbicara dan mengembangkan karakter subjek penelitian dilakukan di siklus II. Oleh karena itu, siklus II dimulai dengan merevisi perencanaan yang sudah dibuat dan materi yang diajarkan adalah Apologizing. Untuk mengumpulkan data, instrument yang telah disiapkan diberikan kepada subjek penelitian.

Hasil perhitungan nilai rata-rata psot-tes II menunjukkan peningkatan keterampilan berbicara dari subjek penelitian. Hal ini dapat dilihat dari nilai rata-rata yang diikuti oleh 30 subjek penelitian yang menghasilkan angka 63,63. Meskipun nilai rata-rata yang dihasilkan masih dikategorikan 'cukup' namun sudah terjadi peningkatan dari pra siklus, siklus I dan siklus II.

Sementara data tentang perkembangan karakter subjek penelitian character checklist menghasilkan perkembangan prosentase membudaya konsisten sebagai berikut: karakter disiplin mengalami peningkatan prosentase menjadi 51,39\%; karakter jujur menjadi 45,84\%; karakter kooperatif sebesar 44,44\%; karakter kreatif bertambah menjadi $45,83 \%$ sedangkan karakter saling menghormati menjadi $41,67 \%$. Prosentase ini menunjukkan peningkatan yang cukup signifikan.

Hasil perhitungan prosentase kuesioner menunjukkan bahwa tidak ada subjek atau $0,00 \%$ subjek memberikan respon sangat tidak setuju dengan penerapan model pembelajaran kolaborasi think-pair-share dengan konsep tri kaya parisudha; $0,31 \%$ subjek penelitian menyatakan tidak setuju; 4,59\% tidak berpendapat; 38,53\% setuju dengan penerapan model pembelajaran dan setengah lebih 
subjek penelitian atau 56,57\% menyatakan sangat setuju.

\section{Siklus III}

Meskipun hasil dari siklus II sudah menunjukkan peningkatan yang konsisten dari pra siklus sampai siklus II, penelitian tetap dilanjutkan ke siklus III.Pada siklus ini, kelemahan-kelemahan yang ditemukan pada siklus sebelumnya menjadi fokus utama untuk melakukan perubahan. Perbaikan-perbaikan tersebut dibuat dalam revisi perencanaan untuk siklus III.Materi yang disampaikan di siklus III adalah agreeing and disagreeing. Untuk mendapatkan data, peneliti kembali memberikan instrument penelitian yang telah disiapkan.

Post-tes III yang diberikan oleh peneliti menghasilkan nilai rata-rata sebesar 77,30.Nilai ini dikategorikan 'baik' dan mengalami peningkatan dari siklus sebelumnya.Hal ini menunjukkan bahwa keterampilan berbicara subjek penelitian meningkat cukup signifikan.

Sedangkan ceklist karakter menunjukkan perkembangan karakter subjek penelitian semakin berkembang dengan baik. Hal ini dibuktikan dengan prosentase karakter yang membudaya konsisten dan terus mengalami peningkatan yaitu karakter disiplin yang meningkat menjadi $65,28 \%$; 56,94\% karakter jujur; $59,72 \%$ karakter kooperatif; 52,78\% karakter kreatif dan $61,11 \%$ karakter saling menghormati.

Meskipun perkembangan karakter sudah memenuhi standar minimal indikator keberhasilan penelitian ini, peneliti belum memutuskan untuk menghentikan penelitian karena keterampilan berbicara subjek penelitian masih belum memenuhi standar kelulusan minimal yang ditetapkan untuk penelitian.Oleh karena itu, penelitian dilanjutkan ke siklus berikutnya yaitu siklus IV.

\section{Siklus IV}

Pada siklus ini tidak terjadi perubahan yang signifikan.Pada siklus IV juga terdapat empat tahapan yang harus dilalui untuk mendapatkan data yang diinginkan dalam penelitian ini. Namun berdasarkan hasil dari siklus III, perbaikanperbaikan yang diperlukan untuk meningkatkan keterampilan berbicara dan mengembangkan karakter subjek penelitian pun dilakukan di siklus IV. Adapun materi yang diajarkan di siklus IV adalah tentang Advice and Suggestion.Pengumpulan datapun kembali dilakukan dengan memberikan post-tes, ceklist karakter dan kuesioner.

Hasil perhitungan nilai rata-rata keterampilan berbicara juga menunjukkan terjadi peningkatan. Post-tes IV yang diberikan kepada subjek penelitian menghasilkan nilai rata-rata sebesar 82,90. Meskipun nilai rata-rata ini juga dikategorikan 'baik' seperti pada siklus sebelumnya, nilai rata-rata pada siklus IV ini meningkat dari 77,30 menjadi 82,90.

Di samping itu, berdasarkan hasil analisa character checklist, perkembangan yang lebih signifikan juga terjadi pada karakter-karakter yang diamati dalam penelitian yaitu: $73,61 \%$ karakter disiplin; 62,50\% karakter jujur; 66,67\% karakter kooperatif; $59,72 \%$ karakter kreatif dan $66,67 \%$ karakter saling menghormati. Hal ini menunjukkan bahwa model pembelajaran yang diterapkan mampu mengembangkan karakter subjek penelitian.

Untuk mendapatkan data pendukung mengenai respon subjek penelitian terhadap penerapan model pembelajaran kolaborasi think-pair-share dengan konsep tri kaya parisudha.Dari hasil analisis data yang dihasilkan dari kuesioner, perhitungan prosentase kuesioner II menunjukkan bahwa tidak ada subjek yang memberikan respon sangat tidak setuju dan tidak setuju dengan penerapan model pembelajaran kolaborasi think-pair-share dengan konsep tri kaya parisudha; hanya $0,43 \%$ subjek penelitian yang menyatakan tidak berpendapat dan 23,58\% subjek menyatakan setuju. Di samping itu subjek penelitian yang sangat setuju dengan penerapan model pembelajaran tersebut meningkat dari $56,57 \%$ menjadi $75,99 \%$.

\section{Pembahasan}

Penelitian tindakan kelas ini berangkat dari permasalahan yang dihadapi oleh subjek penelitian khususnya dalam keterampilan berbicara dan karakter. Penelitian ini diperuntukkan untuk memecahkan permasalahan yaitu: bagaimana peningkatan keterampilan berbicara dan bagaimana perkembangan karakter subjek penelitian setelah 
diajarkan menggunakan model pembelajaran kolaborasi Think-Pair-Share dengan konsep Tri Kaya Parisudha?

\section{Peningkatan Keterampilan Berbicara}

Untuk mengetahui apakah terjadi peningkatan keterampilan berbicara subjek penelitian, peneliti memberikan beberapa tes yaitu pre-tes dan 4 post-tes di siklus I sampai dengan siklus IV. Hasil analisis pre-tes dan post-tes yang menunjukkan peningkatan signifikan seperti pada grafik berikut:

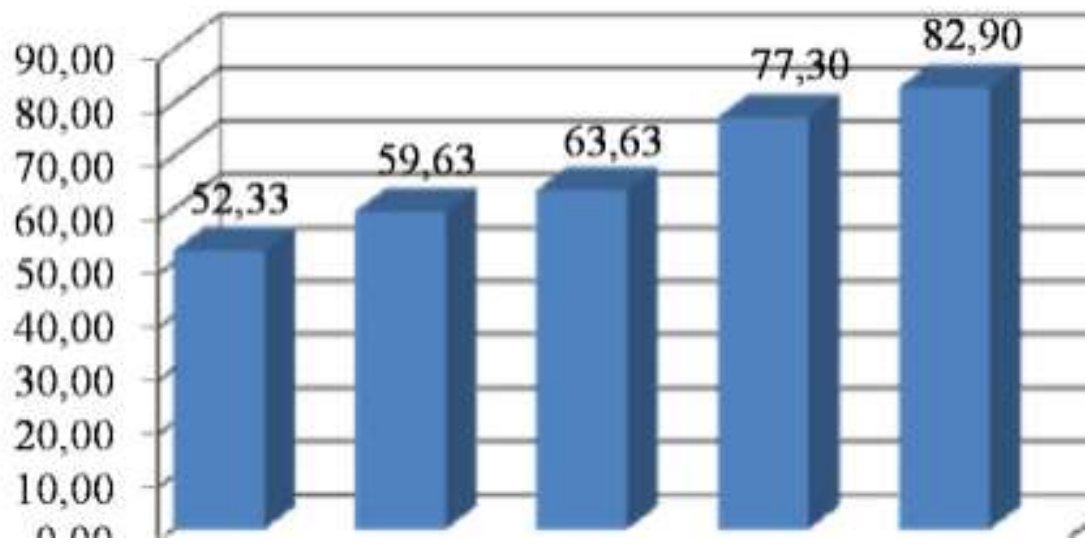

Grafik di atas menunjukkan bahwa penerapan model pembelajaran kolaborasi think-pair-share dengan konsep tri kaya parisudha mengakibatkan peningkatan yang signifikan dalam keterampilan berbicara subjek penelitian. Hal ini dengan jelas dapat dilihat dari peningkatan nilai rata-rata keterampilan berbicara dari subjek penelitian.

Peningkatan nilai rata-rata keterampilan berbicara pada siklus IV sudah memenuhi indikator keberhasilan sehingga penelitian dapat dihentikan. Pada siklus IV, semua subjek penelitian

mendapatkan nilai di sama atau atas 75 yang merupakan standar kelulusan minimal untuk mata kuliah speaking. Oleh karena itu, penelitian tindakan kelas ini akhirnys dihentikan di siklus IV.

\section{Perkembangan Karakter}

Data tentang perkembangan karakter yang diamati dari subjek penelitian dikumpulkan dengan menggunakan character checklist yang diberikan pada saat pra-siklus sampai dengan siklus IV dapat dilihat pada grafik di bawah ini:

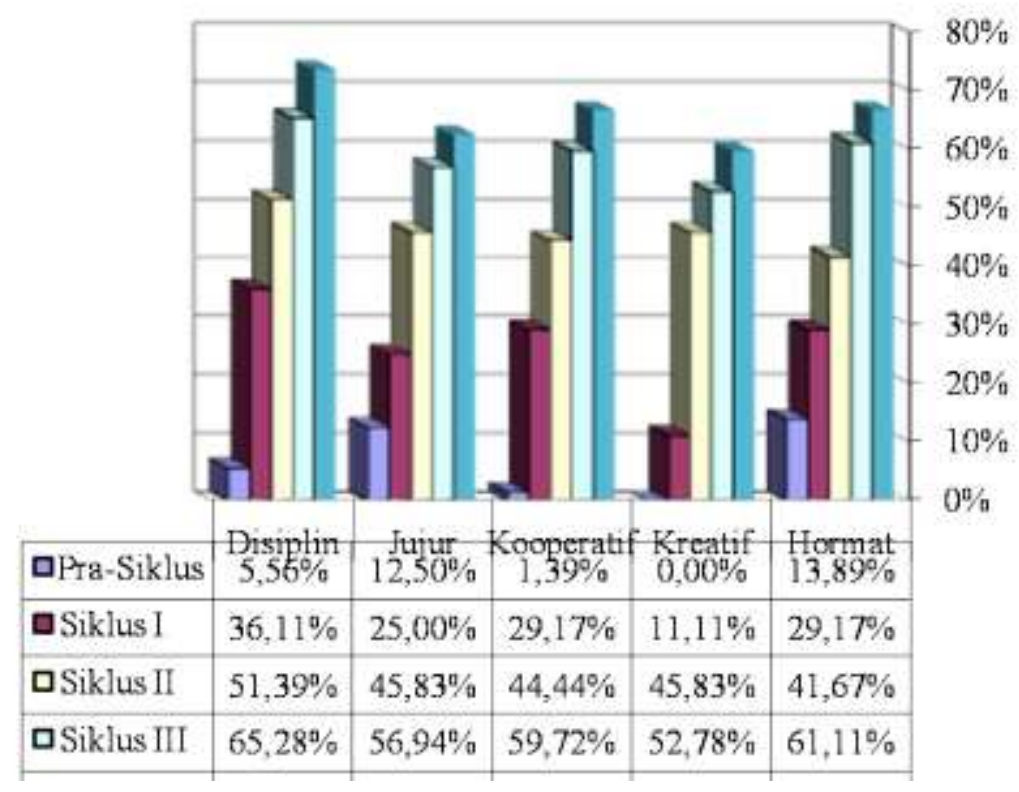


Hasil analisis character checklist menunjukkan hasil yang sejalan dengan peningkatan nilai rata-rata keterampilan berbicara. Perkembangan karakter yang diamati yaitu karakter disiplin, jujur, kooperatif, kreatif dan saling menghormati dari pra siklus sampai dengan siklus IV terjadi dengan konsisten.Hal ini ditunjukkan oleh prosentase masing-masing karakter yang telah membudaya konsisten. Hal ini membuat perubahan tingkah laku subjek penelitian dalam proses pembelajaran.

Perkembangan karakter yang ditunjukkan dengan peningkatan prosentase yang membudaya konsisten juga mengarah pada indikator keberhasilan penelitian ini. Sesuai dengan indikator yang telah ditentukan, penelitian akan dihentikan jika prosentase analisis ceklist karakter telah mencapai minimal 50\% membudaya konsisten. Oleh karena itu, penelitian ini dapat dikategorikan telah berhasil mengembangkan karakter subjek penelitian sehingga penelitian dapat dihentikan.

Data pendukung yang diambil dengan menggunakan kuesioner juga menunjukkan hasil analisis yang positif. Dari hasil analisis, respon subjek penelitian terhadap penerapan model pembelajaran kolaborasi think-pair-share dengan konsep tri kaya parisudha menunjukkan bahwa mereka sangat setuju dengan penerapan model tersebut. Hal ini menunjukkan bahwa model pembelajaran tersebut mampu mengubah atmosfer pembelajaran yang ada di kelas menjadi lebih baik.

\section{KESIMPULAN}

Setelah penerapan model pembelajaran kolaborasi think-pair-share dengan konsep tri kaya parisudha, hasil analisis data yang dihasilkan dari instrumen penelitian yang digunakan menunjukkan peningkatan keterampilan berbicara dari subjek penelitian. Tingkat keterampilan berbicara yang awalnya dikategorikan 'kurang' pada saat pra -siklus meningkat secara signifikan menjadi kategori 'baik' pada siklus IV.Peningkatan ini menunjukkan efektivitas dari model pembelajaran kolaborasi think-pair-share dengan konsep tri kaya parisudha.

Di samping itu, model pembelajaran ini juga memberikan efek yang berbeda terhadap perkembangan karakter subjek penelitian. Karakter- karakter yang diamati yaitu: karakter disiplin, jujur, kooperatif, kreatif dan saling menghormati berkembang secara pelan namun pasti. Hal ini ditunjukkan dengan prosentase oleh tiap-tiap karakter yang membudaya konsisten berada di atas 50\% dan hal ini juga semakin meyakinkan bahwa jika hal ini terus dilanjutkan perubahan tingkah laku pada subjek penelitian akan terbentuk secara permanen.

Data pendukung yang diambil dengan menggunakan kuesioner juga menunjukkan bahwa sebagian besar subjek penelitian atau kurang lebih 75\% memberikan respon yang positif terhadap penerapan model pembelajaran ini. Hal ini semakin meyakinkan bahwa sebagian besar subjek penelitian sangat setuju dengan penerapan model pembelajaran ini.

\section{DAFTAR PUSTAKA}

Arends, R.I. (2007). Learning toTeach (Seventh Edition). New York: the McGraw-Hill Companies.

Baker, J.and Westrup, H.(2003).Essential Speaking Skill: a handbook for Englishlanguage teachers. London: Continuum International Publishing Group.

Brown, H.D. (2004). Language Assessment: Principles and Classroom Practices. White Plains, NY: Pearson Education.

Kayi, H. (2006).Teaching Speaking: Activities to Promote Speaking in Second Language. Nevada, USA: University of Nevada.

Kementerian Pendidikan Nasional (Ditjen Mandikdasmen). (2010). Pendidikan Karakter di Sekolah Menengah Pertama. Jakarta: Kemendiknas Ditjen Mandikdasmen, Direktorat Pembinaan Sekolah Menengah Pertama.

Lawtie, F. (2001). Speaking and Listening Instructional Philosophy and Teaching Suggestions. British Council: Caracas.

Luoma, S. (2004).Assessing Speaking.UK: Cambridge University Press. 
Pemerintah Republik Indonesia. (2010). Desain Induk Pembangunan Karakter Bangsa Tahun 2010-2025.

Richards, J.C. and Rodgers, T.S. (2001).Approaches and Methods in Language Teaching $\left(2^{\text {nd }}\right.$ Edition). New York: Cambridge University Press.

Suhardana, K. (2007). Dan Etika Moralitas Hindu. Surabaya: Paramita

Sumber ilmu. (2013). Tri Kaya Parisudha Sebagai Landasan Pendidikan Dalam Membangun
Akhlak Mulia Peserta Didik diambil pada 8 Maret 2013 dari http://sumberilmu.info/2009/ 01/24/tri-kaya-parisudha-sebagai-landasanpendidikan-dalam-membangun-akhlak-muliapeserta-didik

Wiarto, E.D., Suryana, D.A, Sari, I., Mahmud, M., Zahri, M., Hasmawati, R., Hutauruk, R., Rona, R., Wajiyem, R.,\& Rakhmat, J.(2010). Pendidikan Karakter, Kumpulan Pengalaman Inspiratif. Jakarta: Kementrian Pendidikan Nasional Republik Indonesia. 